\title{
RHINOLOGY
}

\section{A prospective pilot study on the effects of endoscopic sinus surgery on upper and lower airway performance}

\section{Studio prospettico pilota sugli effetti della ESS sulla performance delle vie aeree superiori e inferiori}

\author{
Silvia Atzei', Andrea Melis', Laura Maria De Luca', Maurizio Gaetano Filippo Macciotta ${ }^{2,3}$, Valentina Scano ${ }^{2,3}$, \\ Adriana Pintus ${ }^{4}$, Francesco Tanda ${ }^{4}$, Alessandro Giuseppe Fois ${ }^{2,3}$, Pietro Pirina ${ }^{2,3}$, Angelo Zinellu ${ }^{5}$, Paolo Castiglia ${ }^{3}$, \\ Davide Rizzo ${ }^{1}$, Francesco Bussu',3 \\ ${ }^{1}$ Otolaryngology Division, Sassari University Hospital, Sassari, Italy; ${ }^{2}$ Unit of Respiratory disease, Sassari University Hospital, \\ Sassari, Italy; ${ }^{3}$ Department of Clinical, Surgical and Experimental Medicine, University of Sassari, Italy; ${ }^{4}$ Institute of Histopathology, \\ Sassari University Hospital, Sassari, Italy; ${ }^{5}$ Department of Biomedical Science, University of Sassari, Sassari, Italy
}

\begin{abstract}
SUMMARY
Objective. The relationship between chronic rhinosinusitis, asthma and allergic rhinitis is well known, but only recently has the scientific community started to evaluate these as different manifestations of a common pathogenic phenomenon, considering them as a unified airway disease.

Methods. Twenty-two patients with chronic rhinosinusitis treated with endoscopic sinus surgery (ESS) were included in the study. Sino-nasal assessment questionnaire (SNAQ) investigating subjective evaluation of sino-nasal state was administered to patients, while objective evaluations included nasal endoscopy, sinonasal CT, skin prick tests, nasal cytology, spirometry, bronchodilator responsiveness testing and sputum eosinophil count. All tests were performed before surgery. Two months after surgery, SNAQ questionnaire, nasal endoscopy, spirometry and bronchodilator responsiveness testing were repeated.

Results. All patients had significant improvement of subjective status: mean SNAQ score decreased in all from 99.31 to 16.04 . Mean Forced Expiratory Volume in the $1^{\text {st }}$ second $\left(\mathrm{FEV}_{1}\right)$ significantly improved after surgery from 3.23 to $3.45 \mathrm{~L} / \mathrm{s}$.

Conclusions. ESS achieved a beneficial effect on upper and lower airway status in patients with chronic rhinosinusitis with or without lower airway diseases.
\end{abstract}

KEY WORDS: upper and lower airways, chronic rhinosinusitis and asthma, endoscopic sinus surgery and lower airways, $\mathrm{FEV}_{1}$ and endoscopic sinus surgery

\section{RIASSUNTO}

Obiettivo. La relazione tra rinosinusite cronica, asma e rinite allergica è ben nota, ma solo recentemente la comunità scientifica ha iniziato a considerarle come manifestazioni differenti di un comune evento patogenetico.

Metodi. In questo studio sono stati arruolati 22 pazienti con rinosinusite cronica trattati con chirurgia endoscopica dei seni paranasali (ESS), sottoposti prima dell'intervento chirurgico a Sino-nasal assesment questionnaire (SNAQ) per valutare la sintomatologia soggettiva, endoscopia nasale, TC dei seni paranasali, prick test cutanei, citologia nasale, spirometria con valutazione del volume espiratorio massimo nel 1 secondo $\left(F E V_{1}\right)$, test di broncoreversibilità e misurazione dell'eosinofilia dell'escreato. A distanza di 2 mesi dall'operazione i pazienti sono stati nuovamente sottoposti a SNAQ, endoscopia nasale, spirometria e test di broncoreversibilità Risultati. Tutti i pazienti hanno presentato un miglioramento significativo dei parametri soggettivi (riduzione della media del SNAQ da 99,31 a 16,04), e di quelli oggettivi (media del FEV ${ }_{1}$ da 3,23 a 3,45).

Conclusioni. La chirurgia dei seni paranasali ha dimostrato di apportare benefici sia alle alte che alle basse vie aeree in pazienti con rinosinusite cronica, associata o meno a disturbi delle basse vie aeree.

PAROLE CHIAVE: vie aeree superiori e inferiori, rinosinusite cronica e asma, endoscopic sinus surgery e vie aeree inferiori, $F E V_{1}$ ed endoscopic sinus surgery
Received: January 5, 2021

Accepted: August 19, 2021

Correspondence

Davide Rizzo

Otolaryngology Division, Azienda Ospedaliero Universitaria, Sassari, Italy, viale san Pietro 47, 07100

Sassari, Italy

E-mail: davide.rizzo@aousassari.it

Funding

None.

Conflict of interest

The Authors declare no conflict of interest.

How to cite this article: Atzei S, Melis A, De Luca LM, et al. A prospective pilot study on the effects of endoscopic sinus surgery on upper and lower airway performance. Acta Otorhinolaryngol Ital 2021;41:544-549. https://doi. org/10.14639/0392-100X-N1361

(C) Società Italiana di Otorinolaringoiatria e Chirurgia Cervico-Facciale

\section{(c) (1) $(2)$}

This is an open access article distributed in accordance with the CC-BY-NC-ND (Creative Commons Attribution-NonCommercial-NoDerivatives 4.0 International) license. The article can be used by giving appropriate credit and mentioning the license, but only for non-commercial purposes and only in the original version. For further information: https:// creativecommons.org/licenses/by-nc-nd/4.0/deed.en 


\section{Introduction}

In the last 20 years, emerging pathophysiological evidence led to identify obstructive disease of the lungs and rhinosinusitis as manifestations of a chronic inflammatory respiratory syndrome of the common airways (one-airway disease hypothesis) ${ }^{1}$. Therefore, rhinosinusitis and asthma are not confined to a specific anatomic site, but should be considered as a disorder of the entire respiratory tract, with a range of clinical manifestations and relevant diagnostic and therapeutic implications.

Many studies ${ }^{2}$ have analysed allergic status and pulmonary function in patients with chronic rhinosinusitis (CRS) scheduled for sinus surgery, but few have studied the effects of surgery on the lower airways.

Most studies analysed patients with chronic rhinosinusitis associated with bronchial asthma, but only a very few ${ }^{3}$ evaluated patients without any clinical involvement of the lower airways. Furthermore, while subjective symptoms were well considered in all studies, assessment of the objective parameters was limited to nasal endoscopy and sinonasal CT, for the upper airway, and spirometry and peak expiratory flow, for the lower airway.

The aim of the present work is a comprehensive evaluation of variations of subjective and objective airway parameters in patients who underwent surgery for chronic rhinosinusitis with or without lower airway diseases.

\section{Materials and methods}

A clinical prospective study was carried out during September 2014 - March 2015. We enrolled 22 patients with CRS (with or without nasal polyps) with or without lower airway disease who were referred to the Department of Otorhinolaryngology of the University Hospital of Sassari. All patients underwent endoscopic sinus surgery between September 2014 and March 2015. All procedures performed were in accordance with the ethical standards of the institutional research committee (Sassari ethical committee) and with the 1964 Helsinki declaration and its later amendments or comparable ethical standards.

Exclusion criteria included pathological obesity (body mass index $>40 \mathrm{~kg} / \mathrm{m}^{2}$ ) and important comorbidities (diabetes, immunological diseases, cardiovascular diseases, malignant tumours).

Before surgery, a standard questionnaire (sino-nasal assessment questionnaire-SNAQ), nasal endoscopy, sinonasal CT scan, skin prick tests, nasal cytology, spirometry, bronchial responsiveness testing and sputum eosinophil count were performed. Each patient was re-evaluated 2 months after surgery with SNAQ questionnaire, nasal endoscopy, spirometry and bronchodilator responsiveness testing.
Medical history was collected with a particular regards to atopy, upper airway disease and exposure to risk factors (smoke, occupational factors).

The SNAQ was obtained with the help of a physician for all patients pre- and post-operatively to obtain a subjective score. It was developed in 2002 by Fahmy et al. ${ }^{4}$ to demonstrate the clinical effectiveness of surgery, and includes 11 questions on the clinical complaints of patients. The score attributed to each question, based on the frequency and clinical severity of each symptom, ranges from 0 to 15 and is weighted by multiplying by 3 the first two scores (blocked nose, nasal congestion/stuffy nose) and by 2 the third (facial pain/pressure). Other questions focus on runny nose/anterior nasal discharge, postnasal discharge, sneezing, cough, reduced/altered smell, headache, earache/ear fullness, lack of good night's sleep/tiredness/fatigue. The total score represents the subjective clinical status of each patient.

Skin prick tests were carried out in order to evaluate the presence of early phase IgE reactions. We used Alk-Abellò tests for seasonal allergens (grasses, parietaria, cypress, birch, cynodon dactylon, artemisia, olive tree) and perennial allergens (dermatophagoides pteronyssinus and farinae, epithelium of dog and cat, alternaria). We referred to European Academy of Allergy and Clinical Immunology for the assessment and classification of the results ${ }^{5}$, homogeneously and in continuity with other studies ${ }^{6}$.

Surgery on patients with allergy to seasonal agents is carried out in our institution at least four months before the peak period of involved allergen(s) so that the postsurgical course (as well as postsurgical evaluation of the present work) is not affected by the peak itself.

Nasal mucosal specimens were obtained by scraping the middle one-third of inferior turbinate with Rhinoprobes and stained with May Grunwald-Giemsa. Nasal cytology was examined under an optical microscope (Motic BA210) evaluating the cytopathological findings as recommended by the Italian Academy of Nasal Cytology ${ }^{7}$. Apart from the normal cell population, inflammatory cells (lymphocytes, neutrophils, eosinophils, mast cells), bacteria, or fungal hyphae/spores were identified.

Viral infections, allergic rhinitis, vasomotor rhinitis and overlapping forms can be easily identified. According to the predominant cell type, various entities can be defined: eosinophilic non-allergic rhinitis (NARES), non-allergic rhinitis mast cell (NARMA), neutrophilic non-allergic rhinitis (NARNA), and eosinophil-mast cell non-allergic rhinitis (NARESMA).

Pulmonologists (M.G.F., V.S., A.G.F., P.P.) performed spirometry on a MasterScreen Body plethysmograph JAE$\mathrm{GER}^{\circledR}$, and registered $\mathrm{FEV}_{1}$ in all patients pre- and postoperatively.

In cases of patients showing significant reduction of $\mathrm{FEV}_{1}$ 
compared to the predicted value, a bronchial responsiveness test was carried out by performing a new spirometry after 20 minutes following inhalation of $400 \mu \mathrm{g}$ of salbutamol. If the $\mathrm{FEV}_{1}$ value increased more than $12 \%$ or $200 \mathrm{ml}$ from the previous basal value, asthma was diagnosed, otherwise the diagnosis was chronic obstructive pulmonary disease (COPD). The pulmonary function tests were conducted in observance with the ATS/ERS guidelines for spirometry testing ${ }^{8}$.

A specimen of induced sputum was collected after precautionary inhalation of salbutamol and 20 minutes of isotonic solution $(0.9 \% \mathrm{NaCl})$ nebulization. The conveniently fixed sputum was analysed at the Department of Pathologic Anatomy of the University of Sassari to test the presence of inflammatory cells, particularly eosinophils.

Statistical analysis was performed with the collaboration of the Hygiene Department of the University of Sassari. The impact of surgery on numeric parameters (SNAQ score and $\mathrm{FEV}_{1}$ ) was assessed by paired Student $t$ tests. The influence of concomitant lung diseases, nasal cytology, induced sputum findings, allergy on SNAQ score and $\mathrm{FEV}_{1}$ improvement was also evaluated. A p value $<0.05$ was considered statistically significant.

\section{Results}

Twenty-two patients who underwent endoscopic sinus surgery (ESS) were included in the study (descriptive statistics are reported in Table I).

\section{Preoperative data}

Eight patients had obstructive bronchial diseases: seven patients were previously diagnosed with asthma and two with COPD, while 1 patient was diagnosed with asthma by the tests carried out for this study.

Among the 12 patients showing eosinophils in nasal cytology, atopy was observed in three, while the remaining had non-allergic rhinitis with eosinophils (NARES) ${ }^{9}$.

Eosinophils were detected in nose smears in five of six patients with asthma and in both patients with COPD.

Sputum eosinophilia was observed in 10 patients (45\%) in the entire group and in four of six patients suffering from asthma.

\section{Impact of ESS}

A significant difference in SNAQ score before and after the procedure was observed ( $\mathrm{p}<0.01$ at paired t-test). The mean total SNAQ score was 99.31 before surgery and 16.04 after surgery (Fig. 1). Allergic patients showed a slight higher but non-significant preoperative and postoperative total mean SNAQ scores compared with non-allergic ones (Fig. 2). No significant differences between $\mathrm{FEV}_{1}$ values in allergic and
Table I. Patient data

\begin{tabular}{|c|c|}
\hline \multicolumn{2}{|l|}{ Characteristic } \\
\hline \multicolumn{2}{|l|}{ Age } \\
\hline Mean (range) & $40.1(24-71)$ \\
\hline \multicolumn{2}{|l|}{ Sex } \\
\hline Male & $13(59.1 \%)$ \\
\hline Female & $9(40.9 \%)$ \\
\hline \multicolumn{2}{|l|}{$\mathrm{BMI}$} \\
\hline Median (range) & $26.31(17.85-40.00)$ \\
\hline \multicolumn{2}{|l|}{ Smoking } \\
\hline Yes & $2(9.1 \%)$ \\
\hline No & 20 (90.9\%) \\
\hline \multicolumn{2}{|l|}{ Nasal polyps } \\
\hline CRSWNP & $18(81.8 \%)$ \\
\hline CRS & $4(18.2 \%)$ \\
\hline \multicolumn{2}{|l|}{ Allergy } \\
\hline Yes & $13(59.1 \%)$ \\
\hline No & $9(40.9 \%)$ \\
\hline \multicolumn{2}{|c|}{ Obstructive bronchial disease } \\
\hline Asthma & $6(27.3 \%)$ \\
\hline Asthma + COPD & $2(9.1 \%)$ \\
\hline No asthma & $14(63.6 \%)$ \\
\hline \multicolumn{2}{|l|}{ Nasal cytology } \\
\hline Eosinophilia & 11 (50.0\%) \\
\hline Neutrophilia & $7(31.8 \%)$ \\
\hline Eosinophilia/neutrophilia & $1(4.5 \%)$ \\
\hline Normal & $3(13.7 \%)$ \\
\hline \multicolumn{2}{|l|}{ Rhinitis phenotype } \\
\hline NARES & $2(9.1 \%)$ \\
\hline Allergic rhinitis & $13(59.1 \%)$ \\
\hline NARNE & $5(22.8 \%)$ \\
\hline $\begin{array}{l}\text { NARES/NARNE } \\
\text { Normal }\end{array}$ & $\begin{array}{l}1(4.5 \%) \\
1(4.5 \%)\end{array}$ \\
\hline \multicolumn{2}{|l|}{ Sputum cytology } \\
\hline Eosinophilia & $10(45.5 \%)$ \\
\hline Not assessed & $2(9.0 \%)$ \\
\hline Normal & $10(45.5 \%)$ \\
\hline \multicolumn{2}{|l|}{ Preoperative $\mathrm{FEV}_{1}$} \\
\hline Mean (range) & $3.23(2.00-5.00)$ \\
\hline \multicolumn{2}{|l|}{ Postoperative $\mathrm{FEV}_{1}$} \\
\hline Mean (range) & $3.45(2.04-5.43)$ \\
\hline \multicolumn{2}{|l|}{ Preoperative SNAQ } \\
\hline Mean (range) & $99.31(62-143)$ \\
\hline \multicolumn{2}{|l|}{ Postoperative SNAQ } \\
\hline Mean (range) & $16.04(1-116)$ \\
\hline
\end{tabular}

BMI: Body Mass Index; CRSwNP: chronic rhinosinusitis with nasal polyps; CRS: chronic rhinosinusitis; COPD: Chronic obstructive pulmonary disease; NARES: Non-allergic Rhinitis with Eosinophilia Syndrome; NARNE: Non-allergic Rhinitis with neutrophils; FEV1: Forced Expiratory Volume in the $1^{\text {st }}$ second; SNAQ: sinonasal assessment questionnaire. 


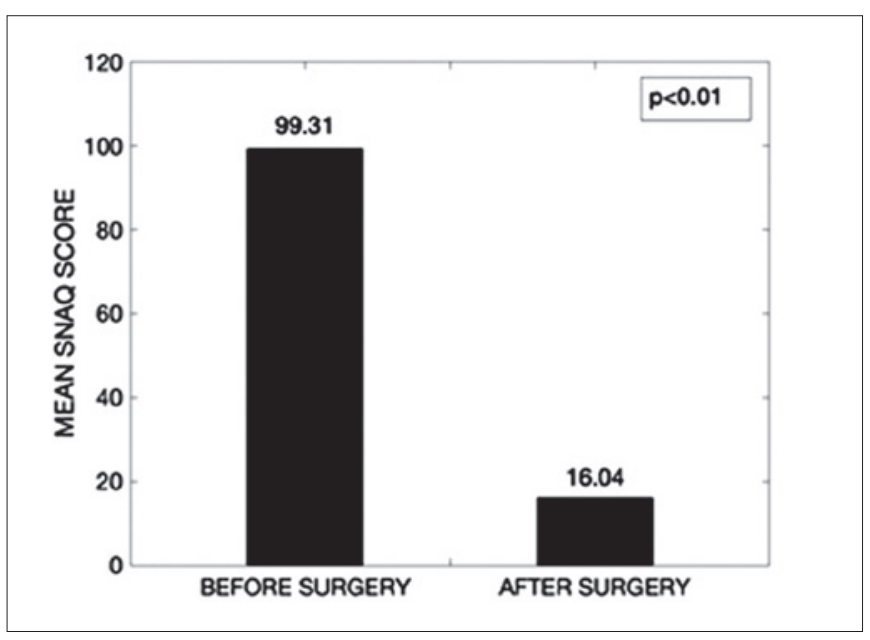

Figure 1. Mean SNAQ score before and after surgery.

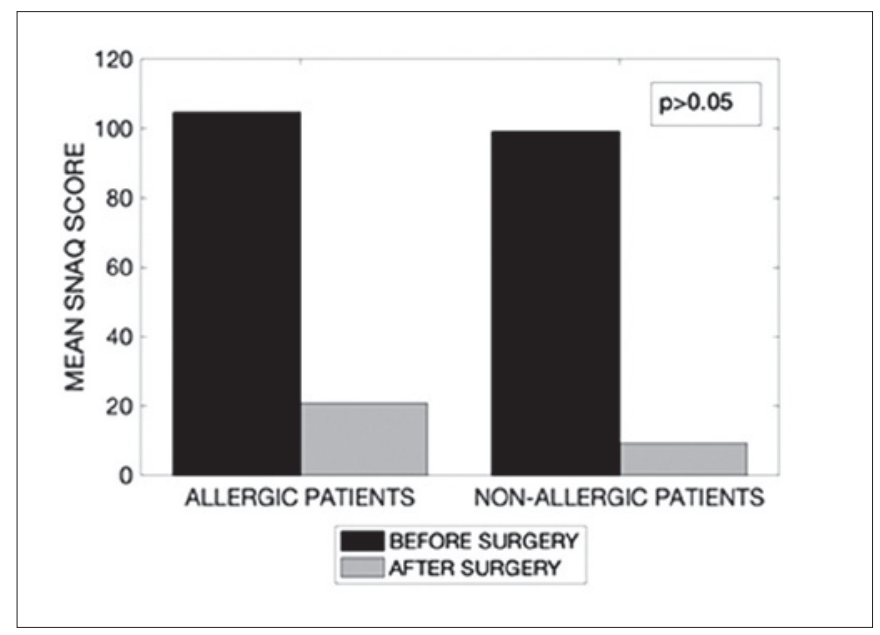

Figure 2. Differences in mean SNAQ score between allergic and non allergic patients.

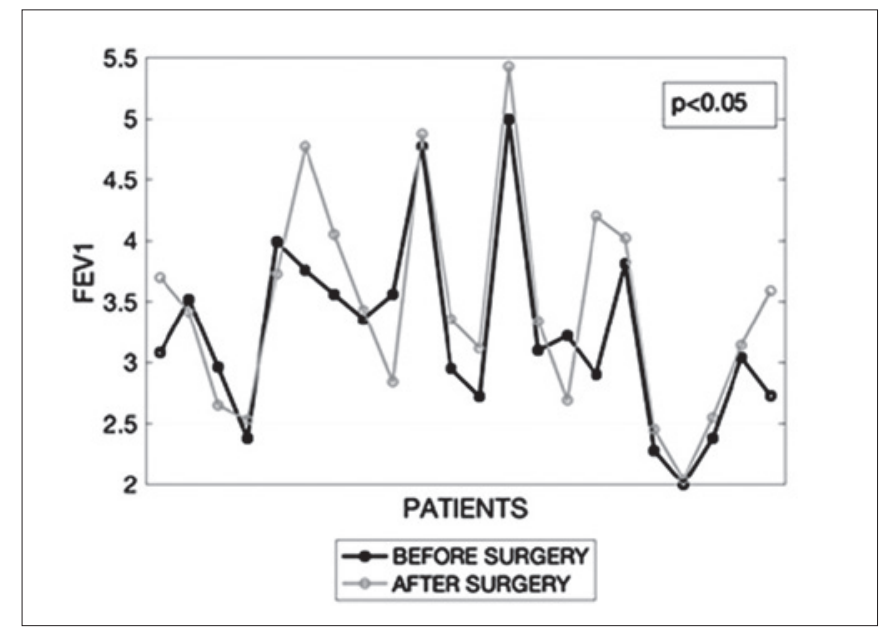

Figure 3. FEV ${ }_{1}$ before and after surgery in the totality of patients. nonallergic patients were detected either before or after ESS. The mean $\mathrm{FEV}_{1}$ was 3.23 before surgery and 3.45 after surgery. A significant improvement in $\mathrm{FEV}_{1}$ before and after the procedure was observed ( $\mathrm{p}<0.05$ at paired t-test) (Fig. 3). No significant differences in SNAQ score and $\mathrm{FEV}_{1}$ improvements were detected in relation to allergic and cytological findings.

When considering only patients with eosinophils in both nasal and bronchial cytology, improvement of SNAQ score and $\mathrm{FEV}_{1}$ lost statistical significance.

\section{Discussion}

Nowadays interactions between upper and lower airways are not completely clear, even if pathophysiologic events causing diseases in both districts are similar. Indeed, CRS and obstructive pulmonary diseases share most cell types, mediators of inflammation, cytokines and neurotransmitters ${ }^{10}$; recently, Samitas et al. ${ }^{11}$ revisited the concept of "one airway disease" identifying a common inflammatory remodelling. Such common factors may also explain the increasing prevalence of chronic bronchitis, defined as "mucus-producing cough on most days for a minimum of 3 months per year and for at least 2 consecutive years", in asthmatic and rhinitic patients despite a decrease in smoking habit ${ }^{12}$. Furthermore, nasal polyposis and asthma seems to share genetic susceptibility factors such as ADRB2 gene polymorphisms ${ }^{13}$. The approach to these issues has drastically changed in the last decade, and the main focus is clearly moving from clinical features (phenotyping) to pathogenic mechanisms (endotyping).

This is a small pilot study with several limitations. Apart from the low numbers, the follow-up is limited and some postoperative data, such as cytology, are not available.

Nonetheless, the present study provides some relevant information: first, even in a small pilot series, it clearly shows the extreme clinical variability of CRS, but at the same time generally confirms the positive impact of ESS not only on the upper, but also on the lower, airways. Although many studies have demonstrated the correlation between the upper and lower airways ${ }^{9,14-16}$, the role of surgery for CRS on the lower airways is still controversial. Furthermore, in most previous studies, few subjective and objective variables were collected ${ }^{17,18}$. For example, many studies have specifically evaluated the impact of ESS on control of symptoms in asthmatic patients, with few investigating the effects on pulmonary function parameters ${ }^{19-21}$; to our knowledge, there are no studies globally evaluating the impact of ESS on pulmonary function in relation with nasal and bronchial cytology and subjective score testing of symptoms.

In the present series, not only did the mean total SNAQ 
score drastically decrease in all patients after surgery, but endoscopic sinus surgery proved to be effective on the lower airways with an improvement of objective parameters, and in particular $\mathrm{FEV}_{1}$. Our results confirm previous data ${ }^{18,20-22}$. Previous studies have shown a correlation between blood eosinophilia and massive nasal polyposis on the one hand ${ }^{23}$ and eosinophils in nasal cytology and asthma on the oth$\mathrm{er}^{24}$. In the present small pilot study, almost all asthmatic patients (five of six) showed the presence of eosinophilia in both nasal and bronchial specimens and patients with nasal and bronchial eosinophilia seem to benefit less, in terms of $\mathrm{FEV}_{1}$, from surgery. This may confirm a further role for both nasal and bronchial cytology in predicting the outcomes of ESS, at least at the level of the lower airways ${ }^{25}$ and may define a group which could benefit from treatment with novel monoclonal antibodies targeting Type 2 inflammation ${ }^{26}$.

Also, based upon this evidence, it can be suggested that, even in absence of specific lower airway disorders, all patients with CRS should undergo a pulmonary medical examination and cytology in order to predict and better define the results of surgery.

\section{Conclusions}

The present results show that endoscopic sinus surgery in CRS patients has a relevant role not only in improving upper airway function, but also in the management of comorbidities associated with the lower airways. Furthermore, it adds useful evidence that support the "one-airway disease" hypothesis ${ }^{1}$, which is in agreement with the current literature. The present data were collected before the end of 2015 and in a small group of patients. In the rapidly evolving world of clinical research in rhinology, the number of patients should be increased and the data should be re-evaluated and enriched with increasingly popular scores (e.g. SNOT ${ }^{27}$, ACT, UPSIT) and information that help in defining the endotype (e.g. FeNO, periostin and blood eosinophils, but also expression of inflammatory cytokines) ${ }^{28}$ and to stratify the results and impact of surgery according to the endotype.

\section{References}

1 Bousquet J, Khaltaev N, Cruz AA, et al. Allergic Rhinitis and its Impact on Asthma (ARIA) 2008 update (in collaboration with the World Health Organization, GA(2)LEN and AllerGen). Allergy 2008;63(Suppl 86):8-160. https://doi.org/10.1111/j.1398-9995.2007.01620.x

2 Håkansson K, Thomsen SF, Konge L, et al. A Comparative and descriptive study of asthma in chronic rhinosinusitis with nasal polyps. Am J Rhinol Allergy 2014;28:383-387. https://doi.org/10.2500/ ajra.2014.28.4076
3 Ikeda K, Tanno N, Tamura G, et al. Endoscopic sinus surgery improves pulmonary function in patients with asthma associated with chronic sinusitis. Ann Otol Rhinol Laryngol 1999;108:355-359. https://doi.org/10.1177/000348949910800407

4 Fahmy FF, McCombe A, Mckiernan DC. Sino nasal assessment questionnaire, a patient focused, rhinosinusitis specific outcome measure. Rhinology 2002;40:195-197.

5 Position paper: Allergen standardization and skin tests. The European Academy of Allergology and Clinical Immunology. Allergy 1993;48:48-82.

6 Muñoz del Castillo F, Jurado-Ramos A, Fernández-Conde BL, et al. Allergenic profile of nasal polyposis. J Investig Allergol Clin Immunol 2009;19:110-116.

7 Gelardi M, Fiorella ML, Leo G, et al. Cytology in the diagnosis of rhinosinusitis. Pediatr Allergy Immunol 2007;18:50-52. https://doi. org/10.1111/j.1399-3038.2007.00634.x

8 Miller MR, Hankinson J, Brusasco V, et al. Standardisation of spirometry. Eur Respir J 2005;26:319-338. https://doi.org/10.1183/0903193 6.05.00034805

9 Ellis AK, Keith PK. Nonallergic rhinitis with eosinophilia syndrome. Curr Allergy Asthma Rep 2006;6:215-220. https://doi.org/10.1007/ s11882-006-0037-0

10 American Thoracic Society Workshop. Immunobiology of asthma and rhinitis. Pathogenic factors and therapeutic options. Am J Respir Crit Care Med 1999;160:1778-1787. https://doi.org/10.1164/ ajrccm.160.5.ats7-99

11 Samitas K, Carter A, Kariyawasam HH, et al. Upper and lower airway remodelling mechanisms in asthma, allergic rhinitis and chronic rhinosinusitis: the one airway concept revisited. Allergy 2018;73:9931002. https://doi.org//10.1111/all.13373

12 Accordini S, Corsico AG, Cerveri I, et al. Diverging trends of chronic bronchitis and smoking habits between 1998 and 2010. Respir Res 2013;14:16. https://doi.org/10.1186/1465-9921-14-16

13 Bussu F, Tiziano FD, Giorgio A, et al. Argl6gly polymorphism of the beta2-adrenoceptor gene (ADRBeta2) as a susceptibility factor for nasal polyposis. Am J Rhinol 2007;21:378-382. https://doi.org/10.2500/ ajr.2007.21.3015

14 Hellings PW, Hens G. Rhinosinusitis and the lower airways. Immunol Allergy Clin North Am 2009;29:733-740. https://doi.org/10.1016/j. iac.2009.08.001

15 Dixon AE. Rhinosinusitis and asthma: the missing link. Curr Opin Pulm Med 2009;15:19-24. https://doi.org/10.1097/ MCP.0b013e32831da87e

16 Virchow JC. Asthma, allergic rhinitis, sinusitis. Concept of the 'unified respiratory tracts'. HNO 2005;53(Suppl 1):S16-S20. https://doi. org/10.1007/s00106-005-1231-4

17 Nakamura H, Kawasaki M, Higuchi Y, et al. Effects of sinus surgery on asthma in aspirin triad patients. Acta Otolaryngol 1999;119:592598. https://doi.org/10.1080/00016489950180856

18 Batra PS, Kern RC, Tripathi A, et al. Outcome analysis of endoscopic sinus surgery in patients with nasal polyps and asthma. Laryngoscope 2003;113:1703-1706. https://doi. org/10.1097/00005537-200310000-00008

19 Ohta N, Suzuki Y, Ikeda H, et al. Efficacy of endoscopic sinus surgery for eosinophilic chronic rhinosinusitis with asthma. Allergol Int 2020;69:144-145. https://doi.org/10.1016/j.alit.2019.08.004

20 Benninger MS, Holy CE. The impact of endoscopic sinus surgery on health care use in patients with respiratory comorbidities. Otolaryngol Head Neck Surg 2014;151:508-515. https://doi.org/10.1177/0194599 $813495815 \mathrm{a} 287$

21 Sujatha S, Suja V. Evaluation of quality of life and pattern of improvement of bronchial asthma in chronic rhinosinusitis patients 
treated by functional endoscopic sinus surgery. Indian J Otolaryngol Head Neck Surg 2019;71:2176-2181. https://doi.org/10.1007/ s12070-019-01586-1

22 Vashishta R, Soler ZM, Nguyen SA, et al. A systematic review and meta-analysis of asthma outcomes following endoscopic sinus surgery for chronic rhinosinusitis. Int Forum Allergy Rhinol 2013;3:788794. https://doi.org/10.1002/alr.21182

23 Newman LJ, Platts-Mills TA, Phillips CD, et al. Chronic sinusitis. Relationship of computed tomographic findings to allergy, asthma, and eosinophilia. JAMA 1994;271:363-367. https://doi.org/10.1001/ jama.271.5.363

24 Harlin SL, Ansel DG, Lane SR, et al. A clinical and pathologic study of chronic sinusitis: the role of the eosinophil. J Allergy Clin Immunol 1988;81:867-875. https://doi.org/10.1016/0091-6749(88)90944-x
25 Gelardi M, Iannuzzi L, De Giosa M, et al. Non-surgical management of chronic rhinosinusitis with nasal polyps based on clinical-cytological grading: a precision medicine-based approach. Acta Otorhinolaryngol Ital 2017;37:38-45. https://doi.org/10.14639/0392-100X-1417

26 Bandi F, Gallo S, Preti A, et al. Effects of biological therapies on chronic rhinosinusitis in severe asthmatic patients. Acta Otorhinolaryngol Ital 2020;40:435-443. https://doi.org/10.14639/0392-100X-N0716

27 Gallo S, Russo F, Mozzanica F, et al. Prognostic value of the Sinonasal Outcome Test 22 (SNOT-22) in chronic rhinosinusitis. Acta Otorhinolaryngol Ital 2020;40:113-121. https://doi. org/10.14639/0392-100X-N0364

28 Fokkens WJ, Lund VJ, Hopkins C, et al. European Position Paper on Rhinosinusitis and Nasal Polyps 2020. Rhinology 2020;58(Suppl S29):1-464. https://doi.org/10.4193/Rhin20.600 